\title{
MULTICULTURAL SPACE: THE STUDY OF KAZAKHSTAN FOLKLORE
}

\author{
Dinara RYSPAYEVA ${ }^{1}$, Ainagul ISMAGULOVA ${ }^{2}$, Alma ZHUKENOVA ${ }^{3}$, Natalia \\ NEMCHENKO ${ }^{4}$
}

\author{
${ }^{1}$ Ph.D., Ms. Sh. Ualikhanov Kokshetau State University, Kazakhstan, goldensunrise@mail.ru \\ ${ }^{2}$ Ph.D., Ms. Sh. Ualikhanov Kokshetau State University, Kazakhstan, ismainagul@mail.ru \\ ${ }^{3}$ Ph.D., Ms. Sh. Ualikhanov Kokshetau State University, Kazakhstan, zhukenalma@rambler.ru \\ ${ }^{4}$ Ph.D., Ms. Sh. Ualikhanov Kokshetau State University, Kazakhstan, nnemchenko@inbox.ru
}

\begin{abstract}
This article is written in the framework of modern linguistic trends and is devoted to the analysis of theoretical and practical peculiarities and difficulties in translating the folklore of over a hundred ethnicities living in Kazakhstan (on the basis of Kazakh, Russian, Tatar, Ukrainian, Polish, Ingush, Armenian and German tales). The main objective is to identify and analyze the ways of translating national cultural peculiarities in folk tales of the ethnicities of Kazakhstan into English. The relevance of this study is determined by the growing interest in folklore, the identification of national and cultural specifics within the modern anthropological paradigm, disclose us the features of linguocognitive content, connection and correlation with the objective world and culture of the ethnos, with the character and national and cultural specifics of the linguistic picture of the world. The article deals with the study of language and culture, which gives possibility to study the link of the language and the language consciousness among representatives of different ethnic groups. The genre of fairy tales in the era of globalization, the spread of mass culture, universal modernization preserves the national and cultural worldview and cultural values of the people. The scientific novelty of this study is displayed through the analysis of the practical experience of translating fairy tales of the Kazakhstani ethnicities into English, which is based on certain theoretical provisions for the translation of the folklore text. The article reveals the results of the ethnic folklore translation into English. The research priority of this study is conceptology, which studies current issues of modern reality, problems of translation, reflecting specific requirements for translating folklore.
\end{abstract}

Keywords: Linguocognitive content, ethnic identity, intercultural communication, folklore, national and cultural specifics.

\section{INTRODUCTION}

In the era of globalization, the spread of mass culture, and general modernization the fairy tale genre preserves the national-cultural worldview and the spiritual values of the people. Children's literature, in particular fairy tales, has a great influence on the spiritual culture of a child, on the formation of its cognitive base, general and individual picture of the world, on its development as a creative personality. Folklore is reflection of the people's ethnic identity and carries the code of the nation, because they describe the way of life of the people, geographical, natural, ethnic conditions, reveals national character.

Today, there is an increasing interest in the research and study of the ethnic folklore. For the multinational Kazakhstan, where the process of ethnic cultural revival is taking place everywhere, the issues of translation, 
study and publication of the ethnic folklore in Kazakhstan are relevant. Kazakhstan represents a multilingual, polyethnic, multicultural and multi-religious country, where people speak languages of different language groups and structural types. It is an example of tolerant attitude of the whole nation to each ethnic group. Various factors consolidated by goodwill of the governance and citizens of the country contribute to this situation. One of such factors is the development of languages of the ethnicities living in Kazakhstan.

One of the characteristic features of the people in the contemporary society is an attempt to study the connection of language units and ethnic identity. To a greater or a lesser degree it concerns younger generation in the period of social adaptation. The process of determination contributes to the development of language identity, ethnic mentality, history and tradition. One of the main reasons for misunderstanding in the course of intercultural communication is cultural differences in the ethnic identity, for the world view is represented through the prism of ethnic culture and language.

The relevance of this study is determined by the growing interest in folklore, the identification of national and cultural specifics within the modern anthropological paradigm allows us to reveal the features of linguocognitive content, connection and correlation with the objective world and culture of the ethnos, with the character, national and cultural specifics of the linguistic picture of the world.

The study of concepts presents the information about a unique phenomenon - the mentality of the ethnicities. Ethnic self-consciousness is based on language, therefore, the analysis of language is the key to the study of the linguistic picture of the world of a given people. The unit of a language is a word which function is to awaken the linguistic consciousness, a certain concept. The folklore text is the main source for the study of certain basic concepts connected with the culture. It is the text that is closely linked with the culture, since it is permeated with a multitude of cultural codes; it is the text that stores information about history, ethnography, national psychology, national behavior, i.e. about everything that makes up the content of culture (V.A. Maslova, 2005, p. 112). The study of language and culture, gives a possibility to study the interconnections of language and the cultural peculiarities of different ethnic groups.

The main objective is to identify and analyze national cultural peculiarities in folk tales of the Kazakhstani ethnicities through the process of translation folklore into English.

The scientific novelty of this study consists in the analysis of the practical experience of translating ethnic fairy tales into English. This study is based on theoretical provisions for the translation of the folklore text. The article reveals the problems and principles of translation, based on the analysis of the folklore and its translation into English.

Translation as a system is focused not only on the adaptation of the text, but also on the transfer of the information that explains and forms the worldview. In this regard, it is very important to study questions of the national characteristics of folklore and how to render them in another language, which in its turn can help develop basic recommendations for a number of translation issues.

This article is the result of a large project based on the translation of the folklore of the ethnic groups in Kazakhstan. The results of the research are presented in the form of a collection of Kazakhstani folk tales in the Kazakh, Russian and English languages. A large layer of folk tales of the ethnoses living in Kazakhstan (Kazakh, Russian, German, Belorusian, Tatar, Ingush, Armenian, Azerbaijani, Uygur, Uzbek, Polish, Korean, Jewish) was translated into English. This practical material became the basis for the study of theoretical and practical features of rendering national and cultural characteristics from one language to another.

\section{THEORETICAL FOUNDATION OF THE RESEARCH}

The present research is based on the achievements in cognitive linguistics, theory of translation of foreign linguists and scientists in Kazakhstan. The features of the concepts with ethnicity colouring should be studied from the point of view of their language representation in English translations. In this regard, it is necessary to identify common basic concepts for the languages of all the studied ethnic groups, along with the peculiarities of the conceptual picture of the world of each ethnos living in the Republic of Kazakhstan.

The goal defines the formulation and solution of the following tasks:

-To analyse the theoretical material on cognitive linguistics and translation studies;

-To distinguish similar basic concepts in fairy tales of the ethnic groups in Kazakhstan

-To identify the ways of verbalization of concepts in their ethno-linguistic interpretation, to conduct an analysis of language representation

-To identify and analyze specific problems of translation of folklore texts 
Theoretical and methodological basis of the study include such scientific theories as the theory of a person or the theory of anthropocentrism (M.Wundt, W. von Humbolt, E. Husserl, E. Cassirer, A.A. Potebnya, L.Feuerbach, G.G. Shpet, G. Shtantile), the theory of conversation (Sh.Bally, M.M. Bahtin, V. Matasius), the theory of speech (W. von Humbolt, U.N. Karaulov, K.L.Austin, A.A. Potebnya), the theory of intercultural communication (V.Wundt, W. von Humbolt, E.F. Tarasov); the works of Russian scientists: N.D. Arutyunova1998 , N.N. Boldyrev 2001 , A. Wierzbicka 1992 , V.I. Karasik1996 , Y.N. Karaulov 1976, E.S. Cubreacova 1997 , V.A. Maslova 2005 , Z.D. Popova 2003, B.A. Serebrennikov1983 , I.A. Sternin 2003.

The Kazakh linguistics is developinhg its own spheres, that comply with the provisions of the modern paradigm of the world linguistics. However, at this stage of development Kazakh linguistics (cognitive linguistics, psycholinguistics, neurolinguistics) is characterized by fragmentation of research (Suleimenova, Shaimerdenova, Zhuravleva, Beisenova, 2009, p. 130). From the ethno-linguistic point of view cognitive aspects of language were explored by K.M. Abisheva 2003, Z.K. Ahmetzhanova 2012, S.Zh. Bayandina 2005, A. Kaydar 2009, M.M. Kopylenko 2010, Zh. Mankeeva 2003, E.D. Suleimenova 2009.

\section{METHODOLOGY}

The present research is based on the achievements in cognitive linguistics, ethnolinguisctics, pragmalinguisctics, theory of translation of foreign scientists and scientists of our country. Complex study of mental, figurative and linguistic representations of concepts in the national world-images involves different parts of the object under study and seems to be the most productive way.

The wide use of disciplines is determined by the supposed pluralism of interpretations, based on the recognition of plurality of conceptions and different approaches to the investigation of the same object, each of them has a certain information about it. Analysis of concepts by means of linguistics and investigation of the conceptual organization of a natural language allows us to get exact and reliable information about universal and ethnic features of the world view of any nation.

The aim and objectives of the study have defined the following methods:

- Conceptual analysis, having a language focus, allows determining the structure and national identity of concepts;

- Descriptive method, involving description of the characteristics of the studied language units;

- Component analysis method, which consists in the interpretation of the values of the test units through a set of inherent semantic components;

- Method of internal reconstruction allows studying development of the linguistic world image of an ethnos, its linguistic consciousness by means of comparison;

- Method of introspection (or method of involved observation) is used in the course of the sampling of the linguistic material for the analysis of the ways of verbalization of the concepts;

\section{DISCUSSIONS}

The main carrier of ethnocultural norms is language. It is used as an intra-ethnic communicative means of preserving traditions, information about the history and culture of the people. The peculiarity of languages lies in the inadequacy of their cognitive bases formed by ethnic groups in the process of perception and mastering the world, specific economic, labor activity, as a result of existence in various socio-ecological landscapes. The dissimilarity of cognitive bases leads to a diverse structuring of the world in the process of the nomination of objects and phenomena. However, many word concepts cannot be understood apart from the intentions of the participants or the social and cultural institutions and behavior in which the action, state or thing is situated (Ctoft, Cruse, 2013, p. 11).

The real world is one, common to all nations. In its development, people rely on a logical model of reality, but the ideas of individuals about objective reality differ. This is the result of the actualization of the linguistic model of the world, based on the principle of complementarity. The specificity of the cognitive mechanisms of cognition of different ethnic groups and the various semantic structuring of the language lead to the problem of mutual understanding between representatives of different linguocultural communities (Abisheva, 2003,p. 18).

The unit of a language is a word whose function is to awaken the linguistic consciousness, a certain concept. However, language is only a mechanism that promotes the coding and translation of culture. Its true keeper is the text. It is the text that is indissolubly linked to culture, since it is permeated with a multitude of cultural codes; it is the text that stores information about history, ethnography, national psychology, national 
behavior, i.e. about everything that makes up the content of culture (V.A. Maslova, 2001, p. 112). In the logical tradition that underlies much work in semantics, concepts are ultimately defined by the truth conditions: the conditions, under which one can say that a concept does, or does not, appropriately apply to a situation in the world (Ctoft, Cruse, 2013, p. 7).

Ethnic groups are in continuous contact. In a multi-ethnic society various languages influence the formation and content of ethnocultural norms. The formation of norms largely depends on the mutual linguocultural competence of ethnocontact groups, on the degree of their compliance with real and desired verbal behavior.

The analysis of folklore (fairy tales, epic stories, legends) helps to recreate the characteristic features of oral folklore. The most important feature of folklore is that it is the art of the spoken word. This is what distinguishes it from literature and other forms of art. Another important distinctive feature of folklore is the collectivity of creativity. It originated as a mass work and expressed the views of the primitive community and the clan, and not of an individual.

\section{NATIONAL AND CULTURAL VARIATION OF THE CONCEPTS IN FOLKTALES}

Analysis of the tales of the ethnic groups of Kazakhstan showed that they have much in common in genres, artistic means, subjects, types of characters, etc. This is explained by the fact that folklore as a type of folk art reflects the general laws of social development of nations. Common features in the folklore of different nations can arise due to the proximity of culture and life or long-term economic, political and cultural ties. Similarity is also played by the similarity of historical development, geographical proximity, movement of peoples, etc.

Translation of folklore raises many difficulties and questions. Each type of folklore, having its own characteristics, requires special attention and approach to translation. The fairy tale is probably the most widely used folklore genre. The fairy tale is a type of folk prose, which is characterized by the presence of fiction. In fairy tales, stories can be fictional, as well as events and characters. According to the composition, a fairy tale, as a rule, has a triple or dual division. The juxtaposition of good and evil, poor and rich, high and low, gives a scheme of construction with double division. The tale tends to formulas.

In the course of the analysis of the folk tales of the ethnic groups of Kazakhstan we came to the following conclusions: there are the traditional beginnings and endings, the numbers 3,7 (9), 12 have a sacred meaning and repeated during the whole text (Once upon a time there was a tsar named Berendey, who had three sons; bowed very low three times...; For three years this camel had not had a colt; The old man begged to be released, and the devil said, "I will let you go if you give me your son, Edygeh, for three years."), (Once upon a time there lived a rich man. He had a lot of cattle and nine sons; The parents of the girls said, "We will give you our nine daughters). There are fabulous formulas connected with the culmination point of the story and transitional formulas between its separate parts. The usual technique is repetition, especially in the dialogues of the folk tales' characters.

In each analyzed tale of the ethnic groups of Kazakhstan there is a main character around which the events unfold. Good and evil, intelligence and stupidity, truth and lies, life and death are openly opposed to each other.

A characteristic feature of folk tales is that the culturally significant, fundamental concepts of "good", "evil", "conscience", "honor", "dignity," happiness"," family "," homeland ", etc. are closely related to each other. The difficulty of the study of these concepts is in the fact that they are dissolved in virtue, happiness, upbringing, family values. The conceptual analysis of the folk tales of the ethnoses of Kazakhstan allows not only to reveal the individual features and ideas about these concepts, belonging to only one ethnic group, but also makes it possible to capture and recognize the main aspects, to trace the dynamics of its development and functioning in a certain situation.

Folklore creates vivid images of a decent and unworthy existence, reflects the values that are significant for a person, complements and completes culturally significant concepts. This article presents an analysis of two fairy tales: the Kazakh folk tale "Edygeh" and the Russian folk tale "The Gray Wolf and Ivan-Tsarevich." Both tales are fairy tales, all the action of these fairies tales is based on magic, where the magic power leaders the process.

There are typical heroes in both fairy tales such as batyr (warrior) Edyge, beautiful Kenzhikey, Shaitan in Kazakh fairy tales; Ivan-Tsarevich, beautiful Helen, Baba Yaga, Koschey Immortal in Russian. There are typical heroes who help to overcome the obstacles in the analysed fairy tales: the Grey-Wolf, the magic horse Djal-Kuiryk, a winged dragon. In both fairy tales, the heroes have to overcome difficulties, in order to achieve the desired goal, the heroes struggle not for life, but for death, defeat enemies, save friends, facing 
evil spirits.

In the analyzed fairy tales, we also encounter the corresponding vocabulary of objects that bear the imprint of that time: Tzar, bow, to guard, chest, kingdom, aul, yurt, bai, Khan, nomadic people.

The hero overcomes obstacles with the help of magic, thus the concept of "miracle" is one of the leading concepts forming the structure of the fairy tales. The linguistic experiment showed that with the word "miracle" the informants have the following associations: these are always positive emotions, surprise, a bright, colorful event, and transformations, something secret, which cannot be explained. Magic items and spells are used in these fairy tales, this concept is presented in this sense, although some wonderful things are described as something ordinary.

A miracle is not complete without magical rituals: the gray wolf caught up with him and said..., The grey wolf uttered a magic spell and became a golden-maned horse, Then the wolf sprinkled Ivan's wounds with the still water, and the wounds healed; it sprinkled him with the water of life, and the prince revived. Take this feather of an owl and burn it when you need to ruin the spell of the devil; Do not be afraid, I will be the first in the race. But you should wind three ropes together and stretch them across the road, in order I could not gallop farther and die.

The analysis shows that the concept "miracle" is leading in fairy tales. It penetrates the fairy tale at all its levels, is the leading component that forms the conceptual sphere of the fairy tales. Everyday life and miracle are described as a single whole; this concept appears as something that is always close to a person.

Another important concept in the analyzed fairy tales is the concept "dignity". The concept "dignity", belonging to the category of moral concepts is one of the basic concepts that forms the worldview of a person. During the analysis, it was revealed that this concept is not objectified by the key lexeme, but manifests itself through peripheral components. In Kazakh fairy tales, lexeme "er" "batyr" are most often encountered. In Russian fairy tales - "tzarevich" (prince), both of these lexemes coincides in the common meaning - "warrior". This lexeme concentrates the main components of the concept's core to represent the individual qualities of a decent, honest, revered, and ready to serve his people person.

The periphery of the concept is represented in the language of fairy tales by the lexemes "zhaksy" (good), "altyn" (golden), "adil" (fair), "'adal" (strong), "vykty"(faithful) expressing the estimated characteristic of a person. Based on the analysis of fairy tales, the following judgments containing the understanding of this concept by Kazakhs can be distinguished:

1) Dignity is the highest value placed above wealth (He had a lot of sheep, oxen and horses. But his greediness was limitless. He didn't respect the sacred tradition of hospitality. A common passer-by couldn't enter his yurt. In his life he had never given a piece of bread to anyone. That was how greedy he was.)

2) A worthy person has a sense of shame, conscience (so now I will serve you faithfully and well. "That's right, friends do not eat each other", said the cat. "But remember, we agreed that if you cheat me, if you steal, I will eat you. Well, you didn't get rid of this bad habit, and so you will die. You ate the butter, I'll eat you." "I know I did wrong; but forgive me, grey wolf.";

3) A decent person is hardworking ("You should not laugh, brother. We did not understand then our father's words. And there was wisdom in his words. He wanted us to go to work in the field at dawn and then whoever passed us will be the first to greet us. When you work hard all day and come home tired and hungry even a stale piece of bread may seem to you sweeter than honey. And then any bed will seem like a welcome and our pleasant sleep will be sweeter than in a down-bed.")

4) Dignity of a person is determined by actions (How shameful! The son of a tsar coming here to steal; So Ivan dismounted from his horse and bowed very low three times, thanking the grey wolf respectfully!)

The lexico-semantic representations of a text event emphasize the importance of the concept "dignity" in the worldview of the analyzed nations, which is not represented by a specific lexeme, but is dissolved in a close connection with such concepts as courage, fearlessness. In the development of the plot of fairy tales, one can' observe the fact that dignity as a trait inherent in the heroes is not passive. Concept "dignity" is active, controlling the life of the hero, being a guide in all situations. The semantics of the concept "dignity" includes moral and national connotations. The feeling of love for the homeland, family encourages a person, to forget about fear, to sacrifice his life in order to defend the honor of his native land, not to drop his dignity and the dignity of his people, his family.

Differences in ethnocommunicative typological knowledge of various nations are manifested mainly in the methods and means of implementing speech activity. The choice of one or another method and means is determined by the speech attitudes of the person and the purpose of communication. The entire set of 
linguistic knowledge of a person is usually involved in the planning and implementation of speech systems. The presence of ethnic and specific in the language is associated with the characteristic features of the vocabulary complex.

\section{ANALYSIS OF THE PRACTICAL EXPERIENCE OF TRANSLATING FOLK TALES OF THE KAZAKHSTAN ETHNICITIES INTO ENGLISH}

\section{Lexical transformations}

The use of this transformation is associated with the characteristics of this genre. In the course of the analysis, it was revealed that the characteristic feature of Russian and Kazakh fairy tales is long and expanded, sentences, describe all the details, therefore, in the process of translation there was a need to omit some points that were not so important and interesting to an English-speaking reader. Having considered all types of lexical transformations used in the translation of Kazakh and Russian folk tales, it can be concluded that the most common method was the omission, which constituted the main percentage (30\%). «Юноша был отослан отцом в другой город и целый год оставался у учителя». - «ТТе youth was sent into another town, and remained a whole year with the master». «Дочка же предупредила обоих - и королевича, и его слугу - чтобы они ничего не пили и не ели, потому что ее мачеха варит одни только отравы». - "The daughter warned the two men to be prudent, to eat nothing, and drink nothing, for the old woman brewed evil drinks».

The nouns "of both the prince and his servant" were omitted here, since earlier these two characters were presented in the fairy tale, and there is no need to repeat the information.

A common technique was also generalization (27\%). «Явился ночью царь муравьиный со своими тысячами муравьев, и благодарные насекомые с великим усердием выбрали просо и сложили его в мешки». - "The King of ants had come in the night with thousands and thousands of ants, and the grateful creatures had by great industry picked up all the millet-seed and gathered them into the sacks».

Lexical additions constituted 17\%: «Мать была радешенька, и королева увезла ее дочку с собою. По приезде в замок королева повела девушку вверх и показала ей три комнаты, снизу доверху полнешеньких чудеснейшего льна». - "The mother was too glad of the offer, and the Queen took the girl with her. When they reached the castle the Queen showed the girl three rooms which were filled with the finest flax as full as they could hold». In this example, the addition of the word "the offer" was used to complete the idea of the sentence.

The absence of the corresponding word or the corresponding lexical-semantic version of this word is also the reason for the introduction of additional words during translation.

«Невеста опять ни слова, и зайчик опять ушел». - «The bride said nothing again and the rabbit went away».

In this sentence, the addition of the word "said" was needed complete to the semantic development. This technique was used to preserve the English grammar and clarity of the thought.

Modulation technique constituted 12\%. «Ах, мне бы очень хотелось ее иметь», - сказал ослик, и стал вдруг такой веселый и радостный, потому что это как раз и было то, чего он желал». - «Ah, yes," said the donkey, "I really like her," and all at once he became quite happy and cheerful, for that was exactly what he was wishing for».

As we can see, the phrase "I would really like to have it" was translated into English as "I really like her". The phrase has been replaced with a reason. In this case, its meaning has undergone a semantic development, within the context.

\section{Peculiarities of using grammatical transformations in translation}

Analyzing the translated fairy tales, it was revealed that the grammatical transformations most often include the literal translation technique, namely in $39 \%$ of cases. The sentences in fairy tales, the meaning of which did not need clarification and did not differ in its structure from the structure of the English language, were mainly translated by means of a literal or direct translation. For example:

«Они были богатые, и было у них все, что они только хотели, но детей у них не было». -«Тhеу were rich, and had everything they wanted, but no children».

In this example, a literal translation is used, since syntactic structures in sentences are similar, and they do not require any grammatical changes. 
The literal translation is most often used and made up the largest part in the translation into English (45\%), but not all the sentences of the Russian and Kazakh languages can preserve the syntactic structure in the translation into English. From this it follows that the use of such techniques as grammatical substitutions are extremely necessary to preserve the meaning of the translated text. Such method as division of sentences and the union (connection) of sentences are used very rarely. This is due to the fact that in the Kazakh and Russian languages of folk tales prevail long sentences that contain a lot of information and for the English tales simple and short sentences are customary. «Наконец, и до того дело дошло, что мать однажды не вытерпела, рассердилась и побила дочку, а та стала голосом плакать».- "Finally the mother became angry, lost her patience and gave her daughter a good beating. The girl was crying loudly».

Grammatical replacement occurred a little less and amounted to $25 \%$.The reason for usage of grammar replacement was different use of words and different norms of compatibility in the English and Russian languages. For example:

«И оттого, что весь мир покинул ее, вышла она, полагаясь на волю господню, в поле». -

"And thus as she was forsaken by the whole world, she went into the open field, relying on God's good will».

The verb "покидать " to leave was referred to the English passive voice «was forsaken».

"Тогда отеи разгневался и сказал: «Ах ты, пропащий человек, сколько ты потерял драгоценного времени, ничему не выучился и не стыдишься мне на глаза показываться!»

"Then the enraged father said: "Oh, you are a lost man! You spent the precious time and learnt nothing. Are you not ashamed to appear before my eyes?!»

The grammatical transformation was the method of combining sentences. It was only 9\%.(«Жила-была маленькая девочка. Отец и мать у ней умерли».- "There was once upon a time a little girl whose father and mother were dead».)

\section{Complex lexical and grammatical transformations}

Complex lexical and grammatical transformations include antonymic translation and explication (descriptive translation).In the process of translation; transformations are most often of mixed type. As a rule, various kinds of transformations are carried out simultaneously, they are combined with each other - replacement is accompanied by a substitution, the grammatical transformation is accompanied by a lexical one. This is a complex nature of translational transformations that makes translation so difficult.

The antonymic translation, which function is the transformation of an affirmative construction into a negative one or vice versa, a negative one in an affirmative one, followed by replacing one of the words of the translated sentence of the original language with its antonym in the translation language, was used in $62 \%$ of cases. (Hе забудь только обещанного нам - в том твое счастье.- Remember what you have promised. It will be all the better for you; и нахвалиться ею не мог - and praised her exceedingly).

According to the study, descriptive translation was used in $38 \%$ of cases. This method of translation is most successfully applied in cases where a relatively brief explanation can be used («Но был у него странный обычай: каждый полдень, когда всё со стола убирали, и никого постороннего не оставалось, приносил ему надежный слуга еще одно блюдо».

"But he had a strange custom: every day after dinner, when the table was cleared, and no one else was present, a faithful servant had to bring him one more dish». - According to the analysis of complex lexical and grammatical transformations, the most frequently used translation method was antonym translation. The predominance of this type of transformation speaks of cultural and linguistic differences that require special attention.

So, there are quite a number of text translation techniques. Each of them, to a certain extent, helps to create a connection between different peoples and nations. They open up new horizons to explore world sources. Comparing the use of various transformations among themselves, it can be summed up that among lexical, grammatical and complex lexical-grammatical transformations, grammatical transformations were used most often, namely in $51 \%$ of cases. This is due to the difference in the structure of Russian and English sentences. Therefore, the translation was carried out in accordance with the rules of the language.

Lexical transformations constituted $43 \%$. This can be explained by the fact that lexical transformations are caused mainly by the fact that the number of meaning of the lexical units of the languages does not coincide.

Complex lexical-grammatical transformations were used least of all, only in $6 \%$ of cases. Complex 
transformations are one of the most complex translation techniques. They require certain skills, vocabulary, imaginative thinking, and excellent knowledge of different cultures, traditions and religions of other countries.

\section{CONCLUSION}

As a result of the analysis of lexicographic and textual material the content and features of the concepts dignity and miracle can be formed, they are undoubtedly important as a way to penetrate the linguistic consciousness of the nation. In their ethnic identity the people see the concept dignity denoting a positive assessment of a person with valuable moral qualities. Connotative meaning is clearly manifested - a high appreciation of society. The concept dignity is one of the key concepts in the linguistic picture of the world, dignity in fairy tales is defined as the most important parameter of a person's life activity, his ethnic labeling and demand, as one of the reference points in the formation of personality with high moral qualities revealing the core of the concept common to all nations.

The analysis of the translation of folk tales of the ethnoses of Kazakhstan showed that the text of a folk tale does not require major structural changes and therefore the leading grammatical methods for translating texts are literal translation and morphological replacement; lexical techniques are used when there is a discrepancy between the volume of values of lexical units and occupy the second largest place among translation methods; complex lexical and grammatical transformations, as complex translation techniques, are not typical for the translation of folk tales.

Revealing the problems and principles of translation makes it possible to investigate comprehensively the combination of ways and means of linguistic expression and the translation of folklore. The comparison of linguistic systems in the process of translation involves the comparison of cultures, cultural specifics, the analysis of the influence of this cultural aspect on the formation of the cognitive processes in a mind.

\section{REFERENCE LIST}

Abisheva, K.M. (2003) Social and linguistic constant activity in the sociolinguistic contactology. Almaty, 18.

Arutyunova N.D. (1998) Language and human world, Moscow/ The Language of Russian culture.

Barsalou, L.W. (1992) Frames, concepts, and conceptual fields. Lehrer AL Kittay E.F. (Eds). Frames, fields and contrasts. New essays in semantic and lexical organization. Hillsdale, N.Jetc: Lawrence Elbaum.

Bayandina, S.ZH. (2005) Cognitive aspects of language functions // Journal of the Kazakh National University Al-Farabi. A series of philological. - Almaty, 2005. - № 3. - p. 76-79.

Boldyrev N.N. (2001) Cognitive semantics: Lectures on English Philology, Tombov, Russia: Tombov State Unversity

Breus, E.V. (2000) Fundamentals of the theory and practice of translation from Russian into English, 2nd ed. Moscow, URAO, 106.

Ctoft, W. and Alan Cruse D. (2013) Cognitive Linguistics. Cambridge University Press, 8-th printing, 7, 11, 14-15.

Cubreacova, E.S. (1997) Parts of speech in terms of cognitive point of view/ Moscow Academy of Sciences of Linguistics, 328.

Frumkina, R.M. (1995). Does the modern linguistics have epistemology? The language and science of the end of the XX cent. / Ed. by StepanovY.S. M: IYAZ RAS, Russian State Humanitarian University.

Janda, Laura A. (2010) Cognitive Linguistics in the Year 2010 // International Journal of Cognitive Linguistic Vol.1. Issue1. Nova Science Publishers, Inc., Haupauge, New York, 6-7.

Karasik V.I. (1996) Cultural dominant ideas in the language: Language personality: cultural concepts. Volgograd; Arkhangelsk: Peremena.

Kubryakova, E.S., Demyankov, V.Z., Pankrats, J.G., Luzina ,L.G. (1997). Concise Dictionary of cognitive terms. M.: Faculty of Philology of Moscow State University.

Likhachev, D.S. (1997). Conceptual sphere of the Russian language. Russian literature. Anthology. Moscow: Academia. 
Maslova, V.A. (2001) Linguoculturology: study guide for students for higher institutions. Moscow:

Academy. 208.

Maslova, V.A. (2005) Cognitive Linguistics: tutorial. Minsk: Tetra Sistems, 256.

Popova, Z.D., Sternin, I.A. (2003). Essays on Cognitive Linguistics. Voronezh: Istoki.

Sdobnikov, V.V. (2007) Theory of translation. Moscow, Vostok-Zapad,448.

Serebrennikov, B.A. (1983) On the materialistic approach to the phenomena of language. - $M$.: Science, 318.

Shaimerdenova, N.Zh. (2015) Children's literature in Kazakhstan: from discussions to solutions. Moscow, Flint: Science, 176.

Suleimenova, E.D., Shaimerdenova, N.Zh., Zhuravleva, E.A., Beisenova ,Zh. S. (2009) Kazakhstan studies of the Russian language (persons). Astana: Saryarka, 250.

Telia, V.N. (1996). Russian phraseology. Semantic, pragmatic and linguistic - cultural aspects. M.: School "Languages of Russian Culture".

Wierzbicka, A. (1992) Semantics, culture and cognition, Universal human concepts in culture - specific configuration. N.Y.; Oxford

Wierzbicka, A. (1996). Language. Culture. Cognition. Moscow: Russian dictionaries. 